\title{
The Effect of The Learning Cell Model on Students' Mathematical Communication Skills
}

\author{
Gusni Satriawati, Adelina Fitriyani, Kadir \\ Syarif Hidayatullah State Islamic University Jakarta, Jl. Ir. H. Djuanda 95, Ciputat, Indonesia \\ E-mail: gusni@uinjkt.ac.id
}

\begin{abstract}
The competence of mathematical communication skill is one of the main factors in learning Mathematics; however, the reality in learning mathematics shows that the students' ability of mathematical communication is still low. The main issues of this study is to analyse the students 'mathematical communication skills using The Learning Cell model and expository learning and to analyze the effect of the application of The Learning Cell model on students' mathematical communication skills. The research method used was a quasi-experimental method with research design of Two Group Randomized Subject Post-Test Only. To know the effect of The Learning Cell model's treatment of mathematical communication skills used Effect Size formula. The total sample was 87 students consisted of 44 students of experimental group and 43 students of control group. The technique of data collection for students' mathematical communication skills used the test instrument on the sub-subject of building a flat side space. The results show that the students' mathematical communication skills are taught with The Learning Cell model is higher than the students' mathematical communication skills with those who taught with expository learning and the Effect Size is in the medium category. The indicators of mathematical communication skills in this research are: (1) representing real objects, drawing diagrams or tables in the form of ideas and mathematical symbols, (2) explaining ideas, situations and mathematical relations in writing using real objects, images, and algebraic expressions, (3) declare everyday events in language or mathematical symbols or arrange mathematical models of events. So, The Learning Cell model is one of mathematics learning that can be used to improve the students' mathematical communication skills.
\end{abstract}

Keywords: The learning cell model, mathematical communication skills, build a flat side space, effect size

\section{INTRODUCTION}

Communication skill is one of the aims of mathematics learning, so needed a good ability to communicate for achieving the purpose of mathematics learning. The importance to have the communication skills, especially in Math lessons which are reinforced by the experts' opinion. Prayitno (2013: 566) states that mathematical communication is needed by the people to communicate ideas or to solve mathematical problems, either in spoken, written, or in visual, such as in mathematical learning or outside of it. According to Polla (Isrok'atun, 2009: 8) mathematical communication is one of the important factors in the learning process of mathematics both inside and outside the classroom. Communication handles an important action in mathematics. Anyone who has a special interest in mathematics will need communication should always add his/her information as much as possible.

However, the reality in learning mathematics, the students' communication skills are still in low level. Based on the interview results with Math teachers at SMPN 3 Tangerang Selatan, students are rarely use mathematical communication skills, so they are difficult to communicate in mathematics, using symbols and translating and developing them in ordinary language or others. This case as result of the teaching applied in the school is the expository or teacher centered learning, where the teacher is still dominant in explaining the subject matter in the class and the students get less opportunity to explore their skills to communicate their ideas in mathematic. Awa's research result (2013) suggests that the highest indicators of students' mathematical communication 
skills are the abilities to declare or illustrate mathematical models into the form of mathematical ideas. According to LACOE, the appropriate way to develop students' mathematical communication skills is in group discussion. In the process of discussion will exchange of ideas and opinion between students. This will provide an opportunity for students to build up their understanding and communication skills of mathematic.

Indicators of mathematical communication skills used in this research are:

1) Represents real objects, images, diagrams or tables in the form of ideas and mathematical symbols

2) Describe ideas, situations and mathematical relationships in writing using real objects, images, and algebraic expressions

3) Stating daily occurrence in a language or mathematical symbol or composing mathematical model of an occurrence

An alternative model of learning that can improve students' communication skills is The Learning Cell model created by Goldschmid in 1976 from Switzerland and then developed again in China by Yu, Yang, and Cheng in 2015. The Learning Cell model is a series of learning activities where at each stage of learning requires students communicate their own ideas and opinions to other students actively (Goldschmid, 1976: 20).

The Steps of The Learning Cell in this study are as follows:

1) Openness

Teachers provide problems those produce variety responses from students about the issues or topics given at the beginning of the lesson. From their answers, then the teachers give tentative or temporary conclusion. Students list the questions after looking at the problems which the teachers revealed, and the question can be asked to other groups to get the answers.

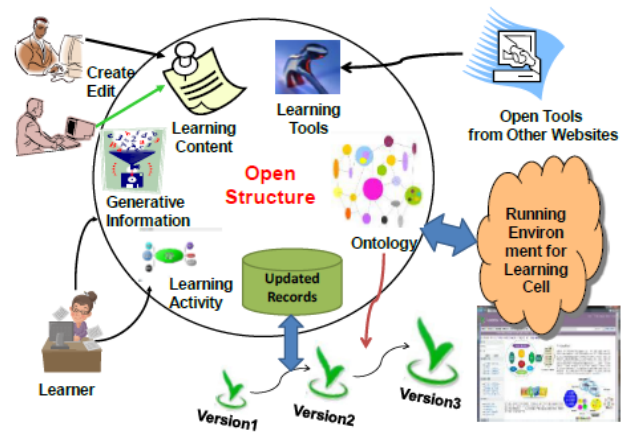

Figure 1. The Openness of the Learning Cell Principles
The open source of learning according to the picture above comes from generative information, learning tools that can openly access learning content, an ontology environment and classroom learning activities. Educators present an open source of learning so that it can trigger various responses from learners who can develop an existing learning resource.

2) Social

Then the teacher divides some groups are even numbered and odd group. The odd group discuss about the content of lesson A, while the even group learn lesson content B. Then each student in the group exchanges information about the content of the lesson discussed. In other hands, each group has to make 2 questions; the odd group makes the question for material B which the even group discussed, and also even group ask for the odd group material.

3) Evolvable \& Context-Aware

After learning the lesson content and preparing 2 questions, every student in group pairs to the other group. One of odd group paired with who in even group (small groups). Activities include asking and answering questions those prepared each other between the groups based on their own topic or material. During this process, the teacher supervises from one couple to another; provides confirmation or feedbacks to the students. Context-Aware is a contextual awareness when students realize what learning or learned at the meeting. Contextual awareness showed from the student's question whether they really investigate for the material discussed or from their reply.

4) Cohesive

All students summarize the materials in accordance with the results of questions and answers with friends. The results of these conclusions are summarized, which is used as the learning resources expand in accordance with the learners' understanding. The conclusions are presented by one member of the group in front of the class.

The application of The Learning Cell model is expected to get the widest opportunity for students to express their mathematical ideas, expresses or clarify their ideas both orally and in written one. Marta Cahyaningrum, et al. (2012) in her research explained that the average learning outcomes of students whose learning using The Learning Cell learning is higher than the average of student learning outcomes that get conventional learning. Rita Khotimah \& Mukhafifah (2011) in their research reveal that there is the effect 
of student learning activity on student's mathematics learning achievement.

Based on the above description, the researcher feels the need to do research with the title "The Effect of The Learning Cell Model to Students' Mathematical Communication Skills".

The problems that will be discussed in this research are (1) how is the students' mathematical communication skill those using The Learning Cell as learning model and those using conventional learning? (2) Are the students' mathematical communication skills those use The Learning Cell as learning model higher than those use conventional learning model?

The purposes of this research are: (1) to analyze the students' mathematical communication skills of the students whose use The Learning Cell and conventional learning model, (2) to analyze the effect of the Learning Cell Model for students' mathematical communication skills.

While the hypothesis in this study, namely "The students' mathematical communication skills those using The Learning Cell are higher than those using conventional learning model".

\section{METHODS}

The method used in this study is the quasiexperimental method, which the researchers unavailable to fully control to the other factors that influence the variables and experimental conditions. Selection method based on considering the research characteristic which intended to analyze the effect of application of The Learning Cell to students' mathematical communication skills. The research design used was posttest-only control group design by taking two randomly selected classes/groups to be used as control group and experimental group. In the experimental group was given special treatment in the form of learning by using The Learning Cell. Meanwhile in the control group, researchers conducted a learning process used expository strategy. Then, both groups were given a post-test to obtain the empirical evidence as seen in the final result, to know whether there is a difference between the experimental group and the control group.

The affordable population in this study were all students in SMP Negeri 3 Tangerang Selatan class VIII registered in the even semester of academic year 2016/2017 consisting of 9 classes. The sample of this study was chosen by using simple random sampling technique from an affordable population.

The instrument used in this study is a test instrument in the form of an essay test to measure the mathematical communication skills of junior high school students. The instrument consisted of 6 pointshaped questions to be given to the experimental group and the control group after both of them had completed the overall learning with the subject of building a flat side room. Instruments tested to both groups have previously been designed by the researcher by making a grid on the subject of building a flat side room adapted to the indicator of the mathematical communication ability to be measured. After that, the researchers made scoring guidelines for assessing student answers. Scoring guidelines required to measure students' mathematical communication skills on each item.

Before the instrument used, firstly the instrument is piloted. This trial is intended to obtain validity, distinguishing power, difficulty, and reliability of the instrument. The data obtained were analyzed using the test of difference of two averages. The test formula used was t-test. To know the effect of The Learning Cell model was used effect Size formula $\left(\mathrm{r}^{2}\right)$ (Kadir, 2015).

\section{RESULTS AND DISCUSSION}

Based on the data processing on the post-test score on the aspect to be measured, those aspects of the students' mathematical communication skills, obtained post-test score for experimental group and control group in Table 1 below. 
Table 1. Comparison of Mathematical Communication Skills of Students of Experiment Class and Control Class

\begin{tabular}{|c|c|c|c|c|c|}
\hline \multirow{2}{*}{ No. } & \multirow{2}{*}{ Indicators } & \multicolumn{2}{|c|}{ Experiment Class } & \multicolumn{2}{|c|}{$\begin{array}{c}\text { Control } \\
\text { Class }\end{array}$} \\
\hline & & $\bar{\lambda}$ & $\%$ & $\bar{x}$ & $\%$ \\
\hline 1. & $\begin{array}{l}\text { Represents real objects, drawings, } \\
\text { and diagrams in the form of ideas and } \\
\text { mathematical symbols }\end{array}$ & 2,24 & 56,10 & 1,74 & 43,47 \\
\hline 2. & $\begin{array}{l}\text { Explain ideas, situations and } \\
\text { mathematical relationships in } \\
\text { writing using real objects, images, } \\
\text { and algebraic expressions }\end{array}$ & 2,50 & 62,50 & 2,06 & 51,42 \\
\hline 3. & $\begin{array}{l}\text { Stating the daily occurrence in a } \\
\text { language or mathematical symbol or } \\
\text { composing mathematical model of } \\
\text { occurrence }\end{array}$ & 3,29 & 82,27 & 2,69 & 67,33 \\
\hline & Avarage & 2,68 & 66,96 & 2,16 & 54,07 \\
\hline
\end{tabular}

Table 1 shows the acquisition of percentage of first indicator of mathematical communication skills that represent real object, drawing, and diagram in the form of idea and or mathematical symbol in experiment class is higher than control class, the percentage equal to $56,10 \%$. It is caused the students in the experimental class who use The Learning Cell especially at the stage of Openness, Social, Evolvable \& Context-Aware and Cohesive make students command in representing images into ideas or mathematical symbols. In addition, they command to work out the problem systematically during the learning activities and always concluding what has been completed so that they can communicate mathematical ideas well. But in the control class, these activities are rarely performed. In indicator 2 it explains ideas, situations, and mathematical relations in writing using real objects, images, and algebraic expressions, the percentage of experimental class is $62,50 \%$ better than control class that is $51,42 \%$.It is caused by the learning process in the experimental class that apply Learning Cell model especially in Social, Evolvable \& Context-Aware and Cohesive there are activities where students are given various information related to the building of flat side space either in the form of statement relating to the daily occurrence and image description, then students are trained to do it by writing in advance what information is contained in the matter so they can use the information available to answer the problem. They command to solve the problems using their own language and explain their answers with drawings or diagrams if necessary to communicate their understanding and mathematical ideas to their classmates. It contrast to the control class in the learning who does not involve the way to communicate mathematical ideas with images, diagrams or tables, the students feel little difficult when finding the problem assigned to illustrate in the form of drawings, diagrams, tables, or algebraic expression resulting in a picture that has not made perfect. In indicator 3 it states daily occurrence in language or mathematical symbol or arrange mathematical model of an occurrence, the percentage of students' mathematical communication skills in experiment class is better than control class, that is $82,27 \%$. Because the experimental class students, especially at the level of Openness, Social, Evolvable $\&$ Context-Aware and Cohesive are familiar with issues related to daily life, so they can solve problems related to daily problems or mathematical situations and then solve them with the language of 
mathematics or compile a mathematical model to solve a problem. While the control class students in the learning process only emphasizes the formulas that must be known to solve the problem it caused the control class students have not been able to declare a mathematical situation, especially in daily life and they completed according to their own answers.

Table 1 presents the comparison of students' mathematical communication skills of the experimental class and control classes based on the three indicators. The percentage of achievement of the students' mathematical communication skills test in the experimental class is $66,96 \%$ while the percentage of students' mathematical communication skills in the control class is $54,07 \%$ or in other words the percentage of mathematical communication skills of the experimental class is higher than the students' mathematical communication in control class.

After hypothetical test of overall mathematical communication skills, $t_{\text {count }}=3,138$ is greater than $t_{\text {table }}=1.663$ so it can be concluded that $\mathrm{H}_{0}$ is rejected, while $\mathrm{H}_{1}$ is accepted. $\mathrm{H}_{1}$ states that with $5 \%$ error degree, the average value of the mathematical communication skills of the students whose learning using The Learning Cell as learning model is higher than using expository. In general, after analysing the results of research, there are several things that cause differences in the average value of the experimental class and control class, one of the reasons is the learning process conducted on the experimental class and control class. This finding means that the learning process with The Learning Cell that contains the Social, Evolvable, and Context-Aware stages is more useful to the students to improve their mathematical communication skills than expository learning. These findings are also in line with the opinion of LACOE (Mahmudi, 2009) which suggests that the appropriate way to increase the mathematical communication skills is in group discussions. This is also in line with Goldschmid's (1972) states that The Learning Cell can improve students' learning achievement more significant when given "unannounced examination" than the students who use conventional learning. In addition to this opinion, the findings of this study also correspond to research conducted by Marta Cahyaningrum, et al. (2012) who found that the average learning outcomes of students whose learning using The Learning Cell were higher than the average learning outcomes of students who get conventional learning. During the learning process, students who use The Learning Cell model tend to be more active in exploring information and knowledge that has not been owned. These findings are in line with research conducted by Rita Khotimah \& Mukhafifah (2011) founded that the influence of student learning activities on student learning achievement mathematics. However, the findings of this study are not in line with the research conducted by Awa (2013) founded that the highest indicator of the students' mathematical communication skills is to express or illustrate mathematical models into the form of mathematical ideas.

\section{CONCLUSION}

Based on the results of the study on the mathematical communication skills of students in SMP Negeri 3 Tangerang Selatan, it can be drawn conclusions as follow:

1. The students' mathematical communication skills who are taught with The Learning Cell model classified as good compared to conventional learning strategies. The highest to the lowest achievement of the indicators of mathematical communication skills of the two learning are similar. The highest achievement obtained on the indicator of the event's mathematical and the contents of the event's mathematical relationships. Or tables in the form of ideas and mathematical symbols.

2. Learning uses The Learning Cell model influences students' mathematical communication skills. The students' mathematical communication skills are taught with learning techniques of The Learning Cell model is more effective in improving students' mathematical communication skills than those are taught with conventional learning models.

\section{ACKNOWLEDGEMENTS}

Firstly, we would like to thank the teachers and students at SMP 3 Tangerang Selatan who have given their support during the research. Secondly, a great thank delivers to colleagues in the department of mathematics education who have sharing their ideas.

\section{REFERENCES}

'Atun, I. (2009). Meningkatkan Komunikasi Matematik Siswa SMP melalui Realistic Mathematics Education (RME) dalam Rangka Menuju Sekolah Bertaraf Internasional (SBI), Journal of Primary Education Nomor 11, p.8. 
Awa, A. et.al. (2016). Analisis Kemampuan Komunikasi Matematik Siswa dalam Memahami Volume Bangun Ruang Sisi Datar, Journal of Mathematics Education, State University of Gorontalo, (http://kim.ung.ac.id).

Bi, X. (2015). Designing the Fliiped Classroom Model Based on The Learning Cell, International Journal of Liberal Arts and Social Sciences, 3(9), p. 65-66.

Cahyaningrum, M. et.al. (2012). Pengaruh Pembelajaran Aktif Strategi Learning Cell Menggunakan Kartu Terhadap Hasil Belajar Siswa SMKN 1 Jetis, Journal of Electro Technique Education, 1(2).

Goldschmid, B., Goldschmid, M.L. (1976). Peer Teaching in Higher Education: A Review, Higher Education, 5(1), p.20.

Kadir. (2015). Statistika Terapan: Konsep, Contoh, dan Analisis Data dengan Program SPSS/Lisrel dalam Penelitian Second Edition, Jakarta: Rajawali Pers, p. 144-146.

Khotimah, R. P., Mukhafifah. (2011). Eksperimentasi Pembelajaran Matematika Melalui Metode Team Quiz dan The Learning Cell Ditinjau dari Aktivitas Belajar Siswa, National Seminar Mathematic Proceeding at Math Education Departement.

Mahmudi, A. (1976), Komunikasi dalam Pembelajaran Matematika, Journal of MIPA, $8(1)$, p. 4.

Mullis, V.S.I., et.al. (2012). TIMSS 2011 International Results in Mathematics, USA: TIMSS \& PIRLS International Study Center.

Team, (2000), Principle and Standard of School Mathematics, Reston: NCTM.

Prayitno, S. et.al. (2013). Komunikasi Matematis Siswa SMP dalam Menyelesaikan Soal Matematika Berjenjang Ditinjau dari Perbedaan Gender, National Seminar Mathematic Proceeding at Math Education Departement, at November 9, p. 566.

Sumarmo, U., Hendriana, H. (2014). Penilaian Pembelajaran Matematika, Bandung: Reflika Aditama.

Yu, S., et. al, (2015). From Learning Object to Learning Cell: A Resource Organization Model for Ubiquitous Learning, Educational Technology \& Society, 18(2), p. 209. 